\title{
PENGARUH NILAI TUKAR RIIL DAN TINGKAT SUKU BUNGA RIIL TERHADAP INDEKS HARGA SAHAM GABUNGAN
}

\author{
I Made Bayu Terayana ${ }^{1}$ \\ Nyoman Triaryati ${ }^{2}$ \\ ${ }^{1,2}$ Fakultas Ekonomi dan Bisnis Universitas Udayana (Unud), Bali Indonesia \\ e-mail: bayuterayana@gmail.com
}

\begin{abstract}
ABSTRAK
Indeks Harga Saham Gabungan dapat menjadi leading indicator economic pada suatu negara. Tujuan dari penelitian ini adalah untuk menguji pengaruh nilai tukar riil dan tingkat suku bunga riil terhadap Indeks Harga Saham Gabungan di Bursa Efek Indonesia. Penelitian ini menggunakan metode kuantitatif berbentuk asosiatif. Sumber data yang digunakan adalah sumber data sekunder dari BEI dan BI. Teknik analisis data yang digunakan dalam penelitian ini menggunakan analisis regresi linear berganda. Hasil penelitian menunjukkan bahwa: Nilai Tukar Riil mempunyai pengaruh positif dan signifikan terhadap Indeks Harga Saham Gabungan (IHSG); dan Tingkat Suku Bunga Riil mempunyai pengaruh negatif dan signifikan terhadap Indeks Harga Saham Gabungan (IHSG). Variabel yang memiliki pengaruh paling besar terhadap IHSG adalah variabel nilai tukar riil.
\end{abstract}

Kata kunci: nilai tukar riil, tingkat suku bunga, dan indeks harga saham gabungan

\begin{abstract}
Composite Stock Price Index can be a leading economic indicators in a country. The purpose of this study is to test the effect of real exchange rate on Composite Stock Price Index in Indonesia Stock Exchange; and the effect of the real interest rate on the Jakarta Composite Stock Price Index. This study uses quantitative methods. Source of data used in this research is secondary data source from BEI and BI. Data analysis techniques used in this study using multiple linear regression analysis. The results showed that: Real exchange rate has a positive and significant influence on Composite Stock Price Index (IHSG); and the Real Interest Rate has a negative and significant influence on the Composite Stock Price Index (CSPI). The variable that has the greatest influence on the IHSG is the real exchange rate variable.
\end{abstract}

Keywords: real exchange rate, real interest rate and joint stock price index 
I Made Bayu Terayana dan Nyoman Triaryati, Pengaruh Nilai Tukar.....

\section{PENDAHULUAN}

Pasar modal dapat dikatakan sebagai penggerak perekonomian dalam suatu negara, karena pasar modal merupakan salah satu bentuk dari modal dan akumulasi dana dalam jangka panjang dan dapat digunakan untuk meningkatkan partisipasi masyarakat untuk menggerakkan dana dalam menunjang biaya pembangunan nasional (Anoraga dan Pakarti, 2011: 11). Pasar modal juga dapat dikatakan sebagai representasi dalam menilai kondisi perusahaan di dalam suatu negara. Dapat dikatakan seperti itu karena semua industri di semua negara dapat diwakili oleh adanya pasar modal. Pasar modal juga menjalankan dua fungsi, yaitu pertama sebagai sarana bagi perusahaan atau sebagai sarana bagi pendanaan usaha untuk memperoleh dana dari masyarakat pemodal atau investor (Mankiw, 2012: 22). Dana yang diperoleh dari pasar modal dapat digunakan sebagai pengembangan usaha, ekspansi, penambahan modal kerja dan lain-lain. Fungsi lainnya dari pasar modal yaitu, menjadi sarana bagi masyarakat untuk berinvestasi pada instrument keuangan seperti saham, obligasi, reksa dana, dan lain-lain (Adiwarman, 2014:12). Karakteristik keuntungan dan risiko masing-masing instrumen dapat diberikan masyarakat melalui penempatan dana yang dimilikinya.

Pasar modal memiliki suatu peranan penting dalam kemajuan perekonomian di Indonesia, yaitu nilai Indeks Harga Saham Gabungan (IHSG) menjadi leading indicator economic pada suatu negara. Pasar modal merupakan suatu sarana pembentukan modal dan akumulasi dana jangka panjang yang ditujukan untuk peningkatan partisipasi masyarakat dalam penggerakan dana guna untuk menujang biaya pembangunan nasional (Nordin dkk., 2014). Pasar modal juga 
dapat digunakan sebagai tolak ukur untuk menilai kondisi suatu perusahaan di suatu negara, karena hampir di semua industri suatu negara terwakili oleh pasar modal (Anoraga dan Pakarti, 2011:13). Investor melalui pergerakan Indeks Harga Saham Gabungan (IHSG), dapat memantau kondisi pasar apakah mengalami kenaikan atau penurunan (Sunariyah, 2012:136).

Indeks Harga Saham Gabungan (IHSG) merupakan indeks yang digunakan untuk menggambarkan pergerakan harga saham secara menyeluruh. Artinya, jika sebagian besar harga saham di bursa mengalami kenaikan maka nilai IHSG akan mengalami kenaikan juga, begitu juga jika sebaliknya (Mgammal dan Hussein, 2012). IHSG merupakan indeks yang diperhatikan oleh investor ketika berinvestasi karena seluruh saham yang tercatat dalam Bursa Efek Indonesia ada di dalam indeks ini. Bentuk informasi yang dipandang sangat tepat untuk mengambarkan pergerakan harga saham di masa lalu adalah suatu indeks harga saham yang memberikan deskripsi harga-harga saham pada suatu saat tertentu maupun dalam periodesasi tertentu pula (Sunariyah, 2012:138).

Faktor internal yang dapat memberikan pengaruh terhadap IHSG antara lain nilai tukar dan tingkat suku bunga (Sukirno, 2012:35). Nilai tukar rupiah merupakan salah satu faktor makroekonomi yang dapat mempengaruhi indeks harga saham. Hal ini disebabkan karena sebagian besar tujuan ekspor Indonesia ke pasar Amerika yang berpengaruh terhadap kondisi perekonomian negara Indonesia (Kuncoro, 2011:65).

Salah satu faktor yang mempunyai pengaruh terhadap IHSG adalah nilai tukar rill (Krisna, 2013). Sekarang ini, kondisi industri indonesia sedang dalam 
I Made Bayu Terayana dan Nyoman Triaryati, Pengaruh Nilai Tukar.....

proses pertumbuhan (Bappenas, 2015:32). Perusahaan-perusahaan tersebut yang aktif dalam melakukan kegiatan ekspor impor. Faktor yang melancarkan kegiatan yang umum digunakan untuk perdagangan internasional adalah Dollar US. Perusahaan-perusahaan yang aktif melakukan kegiatan ekspor dan impor kestabilan nilai kurs mata dollar terhadap rupiah menjadi hal yang penting. Hal ini disebabkan ketika nilai rupiah terdepresiasi dengan dollar US, akan mengakibatkan barang impor menjadi mahal. Padahal sebagian besar bahan baku dalam suatu perusahaan menggunakan bahan impor, dengan demikian akan mengakibatkan kenaikan biaya produksi dan juga akan mengurangi keuntungan suatu perusahaan (Turkyilmaz et al., 2013). Menurunnya keuntungan suatu perusahaan akan berpengaruh terhadap minat beli investor terhadap saham suatu perusahaan bersangkutan. Dampak krisis keuangan global yang dapat terjadi atau dapat dirasakan suatu perusahaan ialah terjadinya penjualan saham-saham di Bursa Efek Indonesia yang dilakukan oleh para investor asing karena mereka membutuhkan uangnya di negara mereka sendiri, maka IHSG dapat mengalami penurunan drastis, dan juga uang rupiah hasil dari penjualan tersebut dibelikan Dollar, yang dapat mengakibatkan nilai rupiah mengalami penurunan, harga saham dalam berbagai jenis perusahaan juga dapat mengalami penurunan (Tandelilin, 2014:211).

Berdasarkan Gambar 1 di bawah dapat dilihat mengenai perkembangan nilai tukar rupiah terhadap Dollar US pada periode 2011-2015. Kondisi nilai tukar rupiah terhadap Dollar US ditahun 2011 hingga 2015 mengalami fluktuasi tapi masih dapat dikatakan stabil karena kenaikan dan penurunan tidak terlalu signifikan kecuali ditahun 2014. Faktor penyebab pelemahan rupiah karena masih 
besarnya permintaan valuta asing berkaitan dengan impor dan sementara itu masih ada keterbatasan dalam ekspor. Di bawah ini merupakan gambaran dari perkembangan nilai tukar tahun 2011-2015:

\section{Gambar 1. Perkembangan Kurs Dollar US Periode 2011-2015}

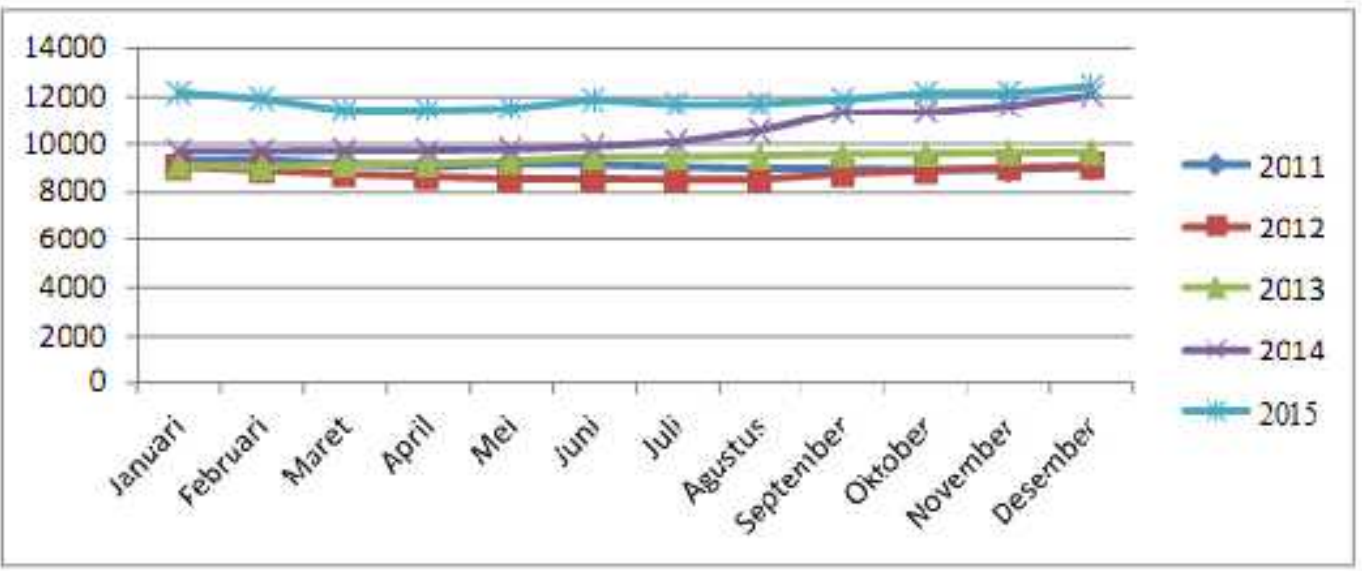

Sumber: www.bi.co.id, 2015

Selain nilai tukar riil, tingkat suku bunga memiliki pengaruh terhadap kenaikan dan penurunan IHSG (Jayanti, 2014). Tingkat suku bunga merupakan daya tarik bagi investor untuk menanamkan investasi dalam bentuk deposito dan SBI. Kenaikan tingkat suku bunga akan meningkatkan beban bunga emiten sehingga labanya akan terpangkas, sehingga akan menekan harga saham. Jika BI Rate turun dan menjadikan suku bunga perbankan menurun maka penurunan tersebut akan menaikkan harga asset, misalnya saham dan surat-surat berharga lainnya. Penurunan suku bunga akan mendorong investasi dan konsumsi. Investor yang berinvestasi ke pasar modal akan mengalami peningkatan pembelian saham yang berarti kenaikan pada IHSG. Di bawah ini merupakan gambar perkembangan tingkat suku bunga tahun 2011-2015: 
Gambar 2. Perkembangan Tingkat Suku Bunga Periode 2011-2015

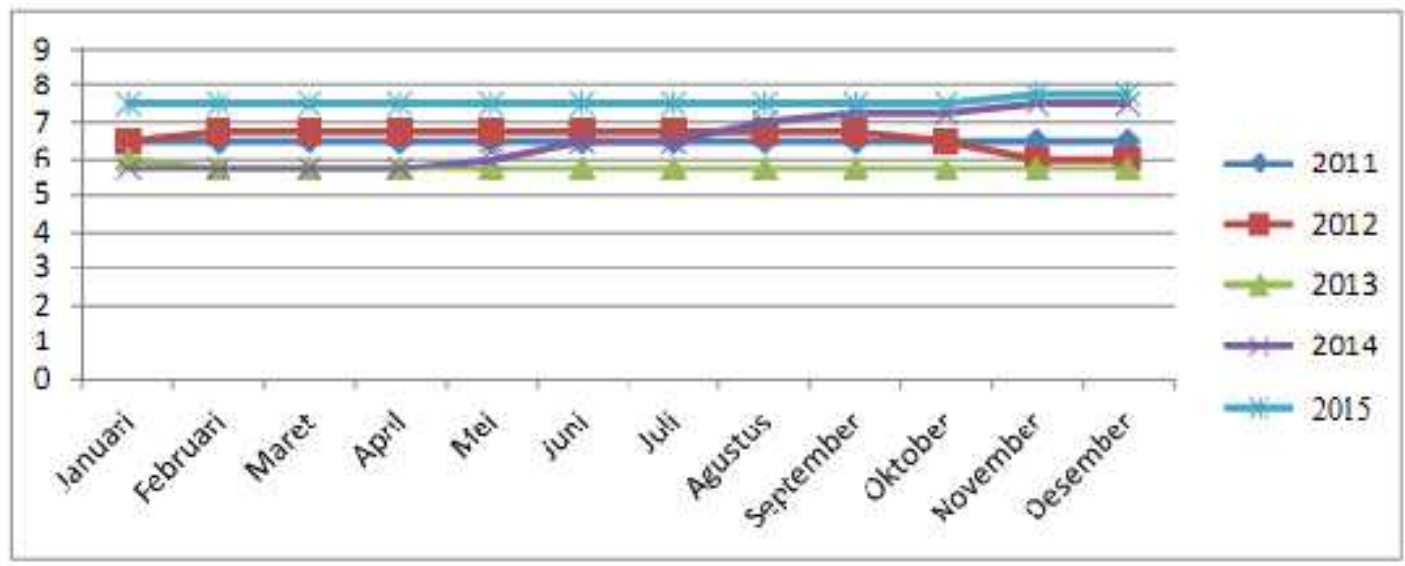

Sumber: www.bi.co.id, 2015

Berdasarkan Gambar 2 perkembangan tingkat suku bunga rata-rata dalam kondisi stabil. Di awal tahun 2011 hingga 2013 tingkat suku bunga mengalami kondisi yang stabil. Lalu pada tahun 2014 kondisi tingkat suku bunga yang stabil mulai naik. Kemudian di tahun 2015 kondisi tingkat suku bunga mengalami kenaikan yang signifikan. Hal ini dikarenakan Bank Indonesia mematok tingkat suku bunga sebesar 6,5\%. Untuk memastikan bahwa inflasi pasca kenaikan BBM berada diposisi yang ditargetkan. Berdasarkan penjelasan tersebut dapat diketahui bahwa faktor ekonomi makro dapat mempengaruhi IHSG.

Berdasarkan Gambar 3 terlihat kondisi perkembangan IHSG di periode 2011-2015. Pada tahun 2011 hingga 2013 IHSG mengalami kondisi yang baik karena disetiap bulannya mengalami kenaikan. Lalu di tahun 2014 IHSG mengalami kenaikan dan penurunan yang cukup signifikan dimana hal ini disebabkan karena kenaikan inflasi, suku bunga, dan nilai tukar yang meningkat. Tahun 2015 mengalami kondisi yang cukup baik dimana IHSG mengalami kenaikan. Meningkatnya IHSG memperlihatkan kondisi pasar modal sedang 
bullish, dan sebaliknya jika terjadi penurunan pada IHSG, maka kondisi pasar modal sedang bearish. Kejadian tersebut dipengaruhi oleh beberapa faktor baik mikro maupun makro ekonomi. Menurut Tobing, Manurung dan Pasaribu (2013) terdapat dua faktor penting yang mempengaruhi IHSG yaitu nilai tukat riil dan tingkat suku bunga. Dari gambar di bawah ini dapat dilihat perkembangan IHSG tahun 2011-2015:

Gambar 3. Perkembangan IHSG Periode 2011-2015

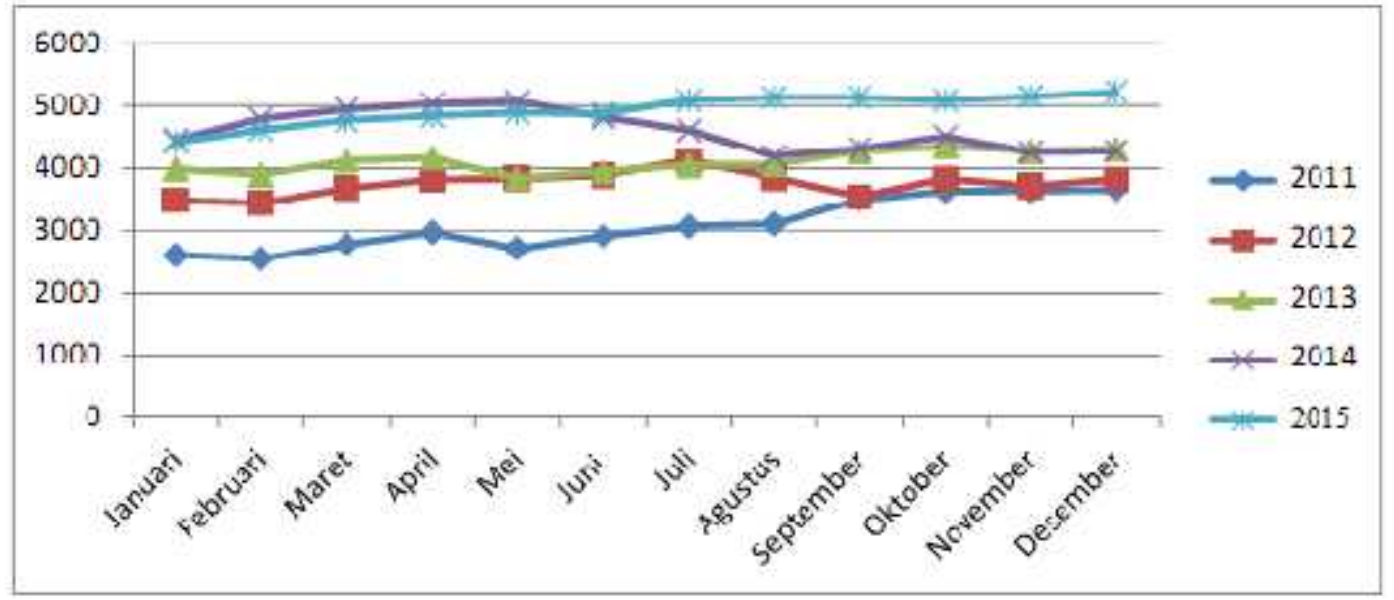

Sumber: www.bi.co.id, 2015

Terkait pengaruh tingkat suku bunga terhadap IHSG, penelitian Hismendi, Abubakar dan Said (2013) menyatakan bahwa tingkat suku bunga riil berpengaruh negatif terhadap IHSG. Artinya kenaikan tingkat suku bunga dapat meningkatkan beban perusahaan yang akan berdampak pada menurunkan harga saham. Kenaikan ini juga potensial mendorong investor mengalihkan dananya ke pasar uang atau tabungan maupun deposito sehingga investasi di lantai bursa turun dan selanjutnya dapat menurunkan harga saham. Hasil penelitian ini didukung oleh hasil penelitian, Kadir, Zarehan, Therisanyo and Reetsang (2011), Alam dan Gazi (2013), Palatte dan Akbar (2014), Nofiatin (2013), Kewal (2012), Alexandra dan 
I Made Bayu Terayana dan Nyoman Triaryati, Pengaruh Nilai Tukar.....

Ilie (2014) serta Novianto (2011) yang menyatakan bahwa tingkat suku bunga riil berpengaruh negatif dan signifikan terhadap IHSG. Hasil penelitian ini bertentangan dengan hasil penelitian Efni (2012), Ananto (2014) dan Murtianingsih (2012) yang menunjukkan bahwa tingkat suku bunga riil berpengaruh positif terhadap IHSG.

Selain permasalahan empiris terkait dengan pengaruh nilai tukar riil terhadap IHSG, dari beberapa hasil penelitian juga terdapat inkonsistensi pengaruh nilai tukar riil terhadap IHSG. Penelitian Hismendi, Abubakar dan Said (2013) serta Jawaid, and Anwar (2012) menunjukkan bahwa nilai tukar berpengaruh negatif terhadap IHSG. Hal ini menunjukkan bahwa bagi investor sendiri, depresiasi rupiah terhadap dollar menandakan bahwa prospek perekonomian Indonesia kurang baik. Sebab depresiasi rupiah dapat terjadi apabila faktor fundamental perekonomian Indonesia tidaklah kuat, sehingga dolar Amerika akan menguat dan akan menurunkan Indeks Harga Saham Gabungan di BEI. Hal ini tentunya menambah resiko bagi investor apabila hendak berinvestasi di bursa saham Indonesia. Investor tentunya akan menghindari resiko, sehingga investor akan cenderung melakukan aksi jual dan menunggu hingga situasi perekonomian dirasakan membaik. Aksi jual yang dilakukan investor ini akan mendorong penurunan return indeks harga saham di BEI. Menurunnya nilai tukar rupiah terhadap mata uang asing, khususnya dollar AS, memiliki pengaruh negatif terhadap ekonomi dan pasar modal. Menurunnya nilai tukar rupiah terhadap mata uang asing meningkatkan biaya impor bahan baku dan peralatan yang dibutuhkan oleh perusahaan sehingga dapat meningkatkan biaya produksi. Menurunnya nilai tukar juga mendorong meningkatnya suku bunga agar dapat mendorong 
lingkungan investasi yang menarik di dalam negeri. Jika perusahaan tidak memiliki pendapatan dari penjualan ekspor maka profitabilitas perusahaan akan menurun dan akan mengakibatkan turunnya harga saham perusahaan tersebut.

Hasil penelitian ini didukung oleh hasil penelitian Octafia (2012), Albuquerque, and Marcelo (2012), Ali Muhammad and Tariq (2015) dan Utami, Mudji serta Mudjilah (2013) dan Engel (2016) yang menunjukan bahwa nilai tukar berpengaruh negatif terhadap IHSG. Pengatan nilai tukar rupiah terhadap mata uang asing akan berdampak pada penurunan biaya impor bahan baku untuk produksi dan akan menurunkan tingkat suku bunga yang berlaku. Hasil penelitian ini bertolak belakang dengan hasil penelitian Sholihah (2014), Bergin and Steven (2012) dan Mulyani (2014) dan Purnomo, Tri serta Nurul (2013) yang menyatakan bahwa nilai tukar dalam jangka panjang akan berpengaruh positif terhadap IHSG. Nilai tukar rupiah yang terdepresiasi terhadap dollar Amerika akan berdampak pada penurunan IHSG, hal ini akan mengakibatkan kegiatan ekspor Indonesia terhambat akibat berkurangnya permintaan dari pasar Amerika.

Rumusan masalah dalam penelitian ini yaitu: 1) Apakah nilai tukar riil berpengaruh signifikan terhadap Indeks Harga Saham Gabungan di Bursa Efek Indonesia?, 2) Apakah tingkat suku bunga riil berpengaruh signifikan terhadap Indeks Harga Saham Gabungan di Bursa Efek Indonesia?. Tujuan dalam penelitian ini yaitu: 1) Untuk menguji pengaruh nilai tukar riil terhadap Indeks Harga Saham Gabungan di Bursa Efek Indonesia, 2)Untuk menguji pengaruh tingkat suku bunga riil terhadap Indeks Harga Saham Gabungan di Bursa Efek Indonesia. 
I Made Bayu Terayana dan Nyoman Triaryati, Pengaruh Nilai Tukar.....

Manfaat dalam penelitian ini yaitu: 1) Manfaat teoritis (penelitian ini diharapkan juga dapat memberikan sumbangan pemikiran kepada dunia keilmuan, khususnya di bidang keuangan sehingga dapat meningkatkan pemahaman terhadap konsep-konsep yang diteliti, mulai dari nilai tukar riil, tingkat suku bunga riil dan indeks harga saham gabungan), 2) Manfaat praktis (Bagi investor dan emiten yang tercatat di BEI, hasil dari penelitian ini dapat membantu mereka dalam menentukan apakah akan menjual, membeli, ataukah menahan saham yang mereka miliki berkenaan dengan fluktuasi nilai rupiah terhadap dolar AS dan tingkat sukubunga. Karena kesalahan dalam menentukan dan menerapkan strategi perdagangan di pasar modal, akan berakibat buruk bagi perusahaan atau investor sehingga dapat mengalami kerugian bila kurs rupiah/US\$, dan tingkat suku bunga berpengaruh terhadap IHSG).

Menurut Tandelilin (2014:221) investasi merupakan suatu tindakan melepaskan dana saat sekarang dengan harapan untuk dapat menghasilkan arus dana masa datang dengan jumlah yang lebih besar dari dana yang dilepaskan pada saat investasi awal (initial investment). Keputusan untuk penanaman modal investasi pada barang-barang modal sangat penting untuk diperhitungkan dan dianalisa sebelum penanaman tersebut dilakukan. Pada dasarnya tujuan orang melakukan investasi adalah untuk menghasilkan sejumlah uang. Berinvestasi pada dasarnya adalah membeli suatu aset yang diharapkan di masa datang dijual kembali dengan nilai yang lebih tinggi. Salah satu alasan utama dari berinvestasi adalah mendapatkan kehidupan yang lebih layak di masa yang akan datang, 
menurangi tekanan inflasi dan dorongan untuk mengemat pajak (Tandelilin, 2014:232).

Kurs merupakan salah satu harga terpenting dalam perekonomian terbuka mengingat pengaruhnya yang demikian besar bagi transaksi berjalan maupun variabel-variabel makro yang lainnya. Oleh karena itulah, kurs juga merupakan sebuah harga aktiva atau harga asset (asset price), sehingga prinsip-prinsip pengaturan harga asset-asset lainnya juga berlaku dalam pengaturan kurs (Salvatore, 2014:07). Nilai tukar terbagi atas nilai tukar riil (real exchange rate) dan nilai tukar nominal (nominal exchange rate). Nilai tukar nominal (nominal exchange rate) adalah nilai yang digunakan seseorang saat menukar mata uang suatu Negara dengan mata uang Negara lain. Sedangkan nilai riil (real exchange rate) adalah nilai yang digunakan seseorang saat menukar barang dan jasa dari suatu Negara dengan barang dan jasa dari Negara lain (Mankiw, 2012:17).

Nilai tukar dipengaruhi oleh beberapa faktor seperti tingkat suku bunga dalam negeri, tingkat inflasi, dan intervensi bank central terhadap pasar uang. Nilai tukar yang lazim disebut kurs, mempunyai peran penting dalam rangka stabilitas moneter dan dalam mendukung kegiatan ekonomi. Ada beberapa faktor yang mempengaruhi pergerakan nilai tukar, yaitu faktor fundamental, faktor teknis, dan sentimen pasar (Madura, 2013:250).

Tingkat suku bunga atau interest rate merupakan rasio pengembalian atas sejumlah investasi sebagai bentuk imbalan yang diberikan kepada investor (Suad Husnan, 2015:193). Suku bunga dibedakan menjadi dua, yaitu: suku bunga nominal adalah suku bunga dalam nilai uang. Suku bunga ini merupakan nilai 
I Made Bayu Terayana dan Nyoman Triaryati, Pengaruh Nilai Tukar.....

yang dapat dibaca secara umum. Suku bunga ini menunjukkan sejumlah rupiah untuk setiap satu rupiah yang diinvestasikan. Suku bunga riil adalah suku bunga yang telah mengalami koreksi akibat inflasi dan didefinisikan sebagai suku bunga nominal dikurangi laju inflasi. Berdasarkan Kamus Akuntansi (2012:107), disebutkan bahwa Interest (bunga, kepentingan, dan hak) merupakan: (1) beban atas penggunaan uang dalam suatu periode, dan (2) suatu pemilikan atau bagian kenyataan dalam suatu perusahaan, usaha dagang, atau sumber daya.

Penelitian Hismendi dkk. (2013) menyatakan bahwa nilai tukar berpengaruh negatif terhadap IHSG. Bagi investor sendiri, depresiasi rupiah terhadap dolar menandakan bahwa prospek perekonomian Indonesia suram. Sebab depresiasi rupiah dapat terjadi apabila faktor fundamental perekonomian Indonesia tidaklah kuat, sehingga dolar Amerika akan menguat dan akan menurunkan Indeks Harga Saham Gabungan di BEI. Hal ini akan mendorong investor untuk melakukan aksi jual terhadap saham-saham yang dimilikinya. Apabila banyak investor yang melakukan hal tersebut, tentu akan mendorong penurunan Indeks Harga Saham Gabungan (IHSG). Aksi jual yang dilakukan investor ini akan mendorong penurunan indeks harga saham di BEI dan mengalihkan investasinya ke dolar Amerika. Hasil penelitian ini didukung oleh hasil penelitian Octafia (2012), Menike (2013), Jamil and Naeem (2013), Utami, Mudji serta Mudjilah (2013), Dimitrova (2015), Habib and Livio (2016) yang menunjukan bahwa nilai tukar berpengaruh negatif terhadap IHSG.

$\mathrm{H}_{1}$ : Nilai tukar riil berpengaruh negatif terhadap IHSG di Bursa Efek Indonesia. 
Penelitian Hismendi dkk. (2013) menyatakan bahwa tingkat suku bunga riil berpengaruh negatif terhadap IHSG. Kewal (2012), Khan, Sangeen, Lala and Imdadullah (2012), Semuel and Stephanie (2015) dan Novianto (2011) yang menyatakan bahwa tingkat suku bunga riil berpengaruh negatif dan signifikan terhadap IHSG. Kenaikan tingkat bunga memiliki dampak negatif terhadap setiap emiten karena akan meningkatkan beban bunga kredit dan menurunkan laba bersih. Penurunan laba bersih akan mengakibatkan laba per saham juga menurun dan akhirnya akan berakibat turunnya harga saham di pasar. Hasil penelitian ini didukung oleh Jayanti, Darminto dan Sudjana (2014), Charles (2012), Anggoro (2011), Irfan (2014) serta Nugraha dan Dewi (2015) yang menyatakan bahwa tingkat suku bunga SBI secara parsial mempunyai pengaruh negatif dan signifikan terhadap IHSG.

$\mathrm{H}_{2}$ : Tingkat suku bunga riil berpengaruh negatif terhadap IHSG.

\section{Gambar 4. Kerangka Konseptual}

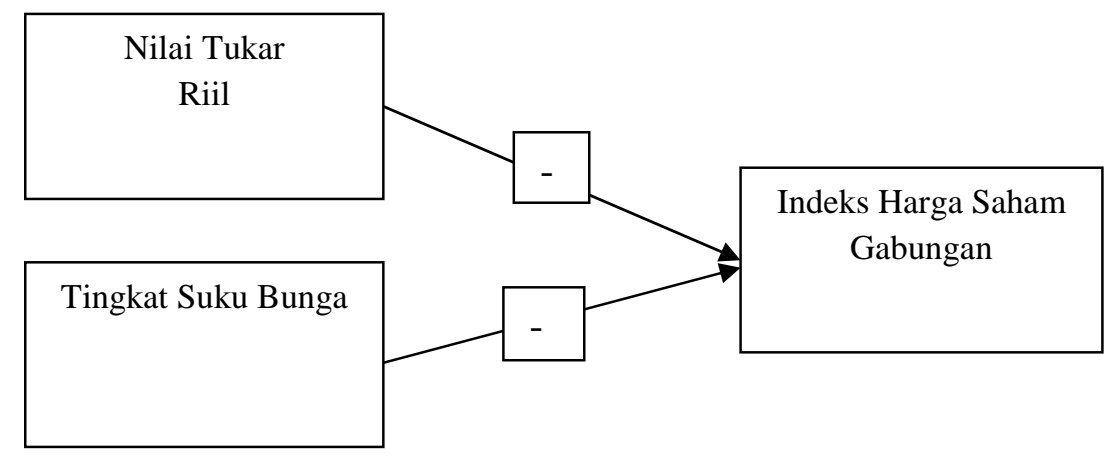

Sumber: Gambar Diolah Peneliti, 2017

Kerangka konseptual merupakan hubungan logis dari landasan teori dan kajian empiris. Kerangka konseptual menunjukkan pengaruh variabel independen 
I Made Bayu Terayana dan Nyoman Triaryati, Pengaruh Nilai Tukar.....

terhadap variabel dependen. Penelitian ini membahas mengenai pengaruh nilai tukar riil dan tingkat suku bunga riil terhadap IHSG. Secara sistematis, kerangka konseptual yang digunakan dalam penelitian ini dapat dilihat pada gambar berikut:

\section{METODE PENELITIAN}

Desain penelitian ini menggunakan metode kuantitatif berbentuk asosiatif. Lokasi penelitian ini dilakukan pada indeks harga saham gabungan yang tercantum di Bursa Efek Indonesia periode 2011-2015. Obyek penelitian ini adalah Indeks Harga Saham Gabungan sebagai variabel dependen (Y) serta nilai tukar riil (X1) dan tingkat suku bunga riil (X2) sebagai variabel independen.

IHSG adalah indeks yang diperoleh dari seluruh saham yang tercatat di Bursa Efek Indonesia dalam satu waktu tertentu. Pengukuran yang digunakan adalah dalam satu satuan poin, dan data yang diperoleh merupakan data IHSG periode 2011 hingga tahun 2015 dengan satuan ribu rupiah.

Nilai tukar riil adalah harga relatif dari barang-barang di antara dua negara. Kurs riil menyatakan tingkat dimana kita bisa memperdagangkan barang-barang dari suatu negara untuk barang-barang dari negara lain. Nilai tukar riil dapat dihitung dengan menggunakan rumus berikut ini:

$$
Q=S \frac{P}{P^{*}}
$$

Dimana:

Q : nilai tukar riil

$\mathrm{S} \quad$ : nilai tukar nominal

$\mathrm{P} \quad$ : tingkat harga domestik

P* : tingkat harga di luar negeri 
Tingkat suku bunga rill adalah konsep yang mengukur tingkat bunga yang sesungguhnya setelah suku bunga nominal dikurangi dengan laju inflasi yang diharapkan. Tingkat suku bunga juga digunakan pemerintah untuk mengendalikan tingkat harga, ketika tingkat harga tinggi dimana jumlah uang yang beredar di masyarakat banyak sehingga konsumsi masyarakat tinggi akan diantisipasi oleh pemerintah dengan menetapkan tingkat suku bunga yang tinggi. Jika $i$ menyatakan tingkat suku bunga nominal, $r$ tingkat suku bunga riil dan $\mathrm{II}^{\mathrm{e}}$ tingkat infasi harapan, maka hubungan diantara ketiga variabel ini dapat ditulis

$$
r=i-I I^{e}
$$

Jenis data yang digunakan dalam penelitian ini adalah data kuantitatif. Data kuantitatif yang digunakan dalam penelitian ini adalah data IHSG, nilai tukar riil, dan tingkat suku bunga riil. Data sekunder pada penelitian ini diperoleh dari situs resmi BEI dan BI melalui www.idx.co.id, www.bi.go.ib, dan www.yahoofinance.com.

Populasi dalam penelitian ini adalah indeks harga saham perusahaan yang diterbitkan oleh BEI. Sampel dalam penelitian ini adalah IHSG dari bulan Januari 2011 sampai Desember 2015. Metode penentuan sampel dalam penelitian ini adalah non probability sampel, yaitu purposive sampling.

Penelitian ini menggunakan tiga tahap analisis yaitu statistik deskriptif, analisis regresi berganda, dan uji asumsi klasik. Persamaan regresi dari penelitian ini adalah sebagai berikut:

$$
\mathrm{Y}=\alpha+\beta_{1} \mathrm{X}_{1}+\beta_{2} \mathrm{X}_{2}+\mathrm{e}
$$


Keterangan :

$$
\begin{array}{ll}
\mathrm{Y} & =\text { Indeks Harga Saham Gabungan (IHSG) } \\
\alpha & =\text { Konstanta } \\
\beta_{1} \text { dan } \beta_{2} & =\text { Koefisien regresi masing-masing variabel independen } \\
\mathrm{X}_{1} & =\text { Nilai Tukar riil } \\
\mathrm{X}_{2} & =\text { Tingkat Suku Bunga Riil } \\
\mathrm{e} & =\text { Random error. }
\end{array}
$$

\section{HASIL DAN PEMBAHASAN}

\section{Uji Analisis Statistik Deskriptif}

Analisis data deskriptif digunakan untuk memberikan deskripsi mengenai variabel yang diteliti terdiri dari Indeks Harga Saham Gabungan (Y), nilai tukar riil (X1) dan tingkat suku bunga riil (X2) disajikan pada tabel 1 sebagai berikut:

\section{Tabel 1.}

\section{Hasil Analisis Deskriptif Statistik}

\begin{tabular}{lrrrrr}
\hline & N & \multicolumn{1}{c}{ Minimum } & \multicolumn{1}{c}{ Maximum } & \multicolumn{1}{c}{ Mean } & \multicolumn{1}{c}{ Std. Deviation } \\
\hline Nilai Tukar Riil & 60 & 8508.00 & 14730.00 & 10880,2167 & 1801.60131 \\
Tingkat Suku Bunga & 60 & 3.82 & 7.55 & 6.1157 & 1.21454 \\
IHSG & 60 & 3470.35 & 5640.37 & 4484.3745 & 553.62423 \\
\hline Valid N (listwise) & 60 & & & & \\
\hline
\end{tabular}

Sumber: Data Diolah, 2017

Berdasarkan Tabel 1 di atas dapat dijelaskan bahwa nilai tukar riil memiliki nilai terkecil sebesar $8.508,00$ artinya bahwa nilai tukar riil terendah yang belaku sebesar 8.508,00 dan nilai terbesar sebesar 14.730,00. Nilai tukar riil memiliki nilai rata-rata sebesar $10.880,2167$ 10.880,2167. Data statistik tersebut menunjukkan sebaran data nilai tukar riil cukup merata. 
Tingkat suku bunga memiliki nilai terkecil sebesar 3,82. Nilai terbesar sebesar 7,55. Tingkat suku bunga memiliki nilai rata-rata sebesar 6,1157. Data statistik tersebut menunjukkan sebaran data tingkat suku bunga cukup merata.

Indeks harga saham gabungan memiliki nilai terkecil sebesar 3.470,35. Nilai terbesar sebesar 5.640,37. Indeks harga saham gabungan memiliki nilai rata-rata sebesar 4.484,3745. Data statistik tersebut menunjukkan sebaran data indeks harga saham gabungan cukup merata.

\section{Hasil Uji Asumsi Klasik}

\section{Uji Normalitas}

Tabel 2.

Uji Normalitas Menggunakan Kolmogrorov-Smirnow Test (K-S)

\begin{tabular}{llr}
\hline & & $\begin{array}{c}\text { Unstandardized } \\
\text { Residual }\end{array}$ \\
\hline $\mathrm{N}$ & Mean & 60 \\
Normal Parameters(a,b) & Std. Deviation & .0000000 \\
& Absolute & 382.49680953 \\
Most Extreme Differences & Positive & .099 \\
& Negative & .099 \\
Kolmogorov-Smirnov Z & & -.087 \\
Asymp. Sig. (2-tailed) & & .768 \\
Sumber: Data Diolah, 2017 & & .597 \\
\hline
\end{tabular}

Hasil penelitian menunjukkan nilai Kolmogorov-Smimov adalah 0,768 dan menunjukkan keadaan yang tidak signifikan dengan nilai derajat probabilitas signifikansi 0,597 atau $p$ value $>0,05$ atau 5\%. Hal ini berarti Ho diterima, yang artinya bahwa data residual berdistribusi normal atau dapat dikatakan telah lolos uji normalitas. 


\section{Uji Multikoliniaritas}

Tabel 3.

Hasil Analisis Multikolinieritas Menggunakan Varian Inflation Factor (VIF)

\begin{tabular}{llcr}
\hline & \multicolumn{1}{c}{ Model } & \multicolumn{2}{c}{ Collinearity Statistics } \\
& Tolerance & VIF \\
\hline 1 & (Constant) & & \\
& Nilai.Tukar.Riil & .626 & 1.597 \\
& Tingkat.Suku.Bunga & .626 & 1.597 \\
\hline Sumber: Data Diolah, 2017 & &
\end{tabular}

Berdasarkan Tabel 3 terlihat bahwa hasil penelitian menunjukkan nilai tolerance tidak kurang dari 0,10 yang berarti tidak ada korelasi antar variabel independen yang nilainya lebih dari 95\%. Sedangkan hasil Variance Inflation Factor (VIF) menunjukkan tidak ada satu variabelpun yang memiliki nilai VIF lebih dari 10. Jadi dapat disimpulkan bahwa tidak ada Multikolonieritas antar variabel independen dalam model regresi.

\section{Uji Autokorelasi}

Tabel 4 menunjukkan bahwa nilai Durbin-Watson adalah 1.954. Nilai ini dibandingkan dengan nilai tabel menggunakan nilai signifikansi 5\%, dengan jumlah sampel sebanyak 40 (n) dan jumlah variabel independen $2(k=2)$ sebagai berikut:

Tabel 4.

Hasil Analisis Uji Autokorelasi Menggunakan Durbin-Watson (DW Test)

\begin{tabular}{|c|c|c|c|c|c|}
\hline Model & $\mathbf{R}$ & R Square & $\begin{array}{l}\text { Adjusted } \\
\text { R Square }\end{array}$ & $\begin{array}{l}\text { Std. Error of } \\
\text { the Estimate }\end{array}$ & $\begin{array}{l}\text { Durbin- } \\
\text { Watson }\end{array}$ \\
\hline 1 & $.723(\mathrm{a})$ & .523 & .506 & 389.14943 & 1.954 \\
\hline
\end{tabular}

Sumber: Data Diolah, 2017

Nilai Durbin-Watson dalam penelitian ini adalah 1.954 yang menunjukkan lebih besar dari batas bawah 1.66 dan kurang dari batas atas 2,34, berdasarkan 
hasil tersebut dapat dikatakan bahwa dalam penelitian ini tidak ada autokorelasi positif atau negatif. Dengan demikian dapat disimpulkan tidak terdapat autokorelasi.

Tabel 5.

Kriteria Keputusan dalam Uji Autokorelasi

\begin{tabular}{lll}
\hline DW & Kesimpulan & Jika \\
\hline Kurang dari 1,08 & Terdapat autokorelasi & $0<\mathrm{d}<\mathrm{dl}$ \\
1,08 s/d 1,66 & Tidak terdapat kesimpulan & $\mathrm{dl} \leq \mathrm{d} \leq \mathrm{du}$ \\
$1,66 \mathrm{~s} / \mathrm{d} 2,34$ & Tidak terdapat autokorelasi & $4-\mathrm{dl}<\mathrm{d}<4$ \\
2,34 s/d 2,92 & Tidak terdapat kesimpulan & $4-\mathrm{du} \leq \mathrm{d} \leq 4-\mathrm{dl}$ \\
Lebih dari 2,92 & Terdapat korelasi & $\mathrm{du}<\mathrm{d}<4-\mathrm{du}$ \\
\hline
\end{tabular}

Sumber: Ghozali (2012:96)

\section{Uji Heterokedastisitas}

Berdasarkan hasil penelitian yang ditunjukkan pada Tabel 6 tidak ada satupun variabel independen memiliki nilai yang signifikan secara statistik dalam mempengaruhi variabel dependen. Hal ini terlihat dari probabilitas signifikansinya di atas 0,05 atau di atas tingkat kepercayaan 5\%, berdasarkan hasil tersebut dapat disimpulkan model regresi tidak mengandung adanya heterokedastisitas.

Tabel 6.

Hasil Analisis Heterokedastisitas Menggunakan Glejser

\begin{tabular}{|c|c|c|c|c|c|c|}
\hline \multirow{5}{*}{1} & \multirow{3}{*}{$\begin{array}{c}\text { Model } \\
\text { (Constant) }\end{array}$} & \multicolumn{2}{|c|}{$\begin{array}{c}\text { Unstandardized } \\
\text { Coefficients }\end{array}$} & \multirow{2}{*}{$\begin{array}{c}\text { Standardized } \\
\text { Coefficients }\end{array}$} & \multirow{3}{*}{$\begin{array}{c}\mathbf{t} \\
-.626\end{array}$} & \multirow{3}{*}{$\begin{array}{l}\text { Sig. } \\
.534\end{array}$} \\
\hline & & B & Std. Error & & & \\
\hline & & -202.427 & 323.161 & & & \\
\hline & Nilai.Tukar.Riil & .021 & .036 & .099 & .586 & .560 \\
\hline & Tingkat.Suku.Bunga & -3.486 & 52.816 & -.011 & -.066 & .948 \\
\hline
\end{tabular}

\section{Uji Koefisien Determinasi}

Hasil penelitian yang ditunjukkan pada tabel 7 terlihat bahwa besarnya $\mathrm{R}^{2}$ adalah 0,523 atau 52,3\% variabel dependen IHSG dipengaruhi oleh variabel 
independen nilai tukar riil dan tingkat suku bunga, sedangkan sisanya 47,7\% (100\%-52,3\%) dijelaskan oleh sebab-sebab yang lain di luar model penelitian.

Tabel 7.

Koefisien Determinasi

\begin{tabular}{llrrrr}
\hline Model & R & R Square & $\begin{array}{c}\text { Adjusted } R \\
\text { Square }\end{array}$ & $\begin{array}{c}\text { Std. Error of } \\
\text { the Estimate }\end{array}$ \\
\hline 1 & $.723(\mathrm{a})$ & .523 & .506 & 389.14943 \\
\hline Sumber: Data Diolah, 2017 & & &
\end{tabular}

\section{Uji Kelayakan Model (Uji F)}

Hasil penelitian yang ditunjukkan pada tabel 8 di ketahui bahwa nilai probabilitas signifikansi atau $p$ value-nya adalah 0,000 yang berarti lebih kecil dari 0.05 atau $5 \%$ dan nilai $\mathrm{f}_{\text {hitung }}$ sebesar 31.206 lebih besar dari nilai $\mathrm{f}_{\text {tabel }}$ sebesar 2,145 dengan demikian secara bersama-sama nilai tukar riil dan tingkat suku bunga riil berpengaruh terhadap Indeks Harga Saham Gabungan.

Tabel 8.

Hasil Uji Silmutan (Uji-F)

\begin{tabular}{cccccc}
\hline Model & Sum of Squares & df & Mean Square & F & Sig \\
\hline 1 Regression & 9451563 & 2 & 4725781.451 & 31.206 & $.000^{\mathrm{a}}$ \\
Residual & 8631925 & 57 & 151437.276 & & \\
Total & 18083488 & 59 & & & \\
\hline
\end{tabular}

Sumber: Data Diolah, 2017

\section{Analisis Regresi Linear Berganda}

Tabel 9.

Analisis Regresi Linear Berganda

\begin{tabular}{|c|c|c|c|c|c|}
\hline \multirow[b]{2}{*}{ Model } & \multicolumn{2}{|c|}{$\begin{array}{c}\text { Unstandardized } \\
\text { Coefficients }\end{array}$} & \multirow{2}{*}{$\begin{array}{c}\begin{array}{c}\text { Standardized } \\
\text { Coefficients }\end{array} \\
\text { Beta } \\
\end{array}$} & \multirow{3}{*}{$\begin{array}{c}\mathbf{t} \\
7.124\end{array}$} & \multirow{3}{*}{$\begin{array}{l}\text { Sig. } \\
.000\end{array}$} \\
\hline & B & Std. Error & & & \\
\hline 1 (Constant) & 2292.226 & 321.754 & & & \\
\hline Nilai.Tukar.Riil & .256 & .036 & .833 & 7.205 & .000 \\
\hline Tingkat.Suku.Bunga & -97.127 & 52.719 & -.213 & -2.842 & .006 \\
\hline
\end{tabular}


Dari hasil penelitian yang ditunjukkan pada Tabel 9, maka persamaan regresi yang di dapat adalah sebagai berikut:

$$
\mathrm{Y}=2.292+0,256 \mathrm{X}_{1}-97,127 \mathrm{X}_{2}
$$

Keterangan:

$$
\begin{aligned}
& \mathrm{Y}=\text { Indeks Harga Saham Gabungan } \\
& \mathrm{X}_{1}=\text { Nilai Tukar Riil } \\
& \mathrm{X}_{2}=\text { Tingkat Suku Bunga }
\end{aligned}
$$

Berdasarkan persamaan di atas dapat dilakukan interpretasi bahwa koefisien regresi $\mathrm{b} 1=0,256$ (signifikan) mempunyai arti bahwa nilai tukar riil sebesar $1 \%$ akan menaikkan IHSG sebesar 0,256 (faktor lain dianggap tetap). Sementara itu, koefisien regresi b2 $=-97,127$ (signifikan) mempunyai arti bahwa tingkat suku bunga sebesar 1\% akan menurunkan IHSG sebesar -97,127 (faktor lain dianggap tetap).

\section{Uji Parsial (Uji t)}

\section{Pengaruh Nilai Tukar Riil terhadap Indeks Harga Saham Gabungan}

Hasil analisis statistik yang ditunjukkan pada tabel 9, dapat dilihat bahwa nilai probabilitas signifikansi atau sig.-nya adalah 0,000 atau lebih kecil dari 0.05 atau 5\%. Selain itu berdasarkan hasil analisis diperoleh nilai $t_{\text {hitung }}$ sebesar 7,205 lebih besar dari nilai $t_{\text {tabel }}$ sebesar 1,969. Sehingga hipotesis yang menyatakan nilai tukar riil berpengaruh negatif terhadap Indeks Harga Saham Gabungan di Bursa Efek Indonesia dinyatakan ditolak 
I Made Bayu Terayana dan Nyoman Triaryati, Pengaruh Nilai Tukar.....

\section{Pengaruh Tingkat Suku Bunga terhadap Indeks Harga Saham Gabungan}

Hasil analisis statistik yang ditunjukkan pada tabel 9, dapat dilihat bahwa nilai probabilitas signifikansi atau sig.-nya adalah 0,006 atau lebih kecil dari 0.05 atau 5\%. Selain itu berdasarkan hasil analisis diperoleh nilai $t_{\text {hitung }}$ sebesar $-2,842$ lebih besar dari nilai $t_{\text {tabel }}$ sebesar $\pm 1,969$. Sehingga hipotesis yang menyatakan tingkat suku bunga riil berpengaruh negatif terhadap Indeks Harga Saham Gabungan di Bursa Efek Indonesia dinyatakan diterima.

\section{PEMBAHASAN HASIL PENELITIAN}

Hasil penelitian ini menunjukkan ada pengaruh positif dan signifikan secara parsial nilai tukar riil terhadap indeks harga saham gabungan. Hasil penelitian ini mendukung penelitian empirik yang dilakukan oleh Octavia (2014) serta Suciwati dan Machfoedz (2012) yang menyatakan bahwa nilai tukar riil berpengaruh positif terhadap IHSG. Temuan penelitian ini memiliki implikasi bahwa ketika nilai tukar rupiah mengalami peningkatan juga akan diikuti dengan peningkatan indeks harga saham gambungan. Pengaruh positif yang diberikan variabel nilai tukar riil terhadap IHSG menunjukkan bahwa penguatan kurs US dollar (rupiah terdepresiasi) justru akan meningkatkan IHSG. Hal ini terjadi karena penurunan nilai tukar riil mengakibatkan makin murahnya produk ekspor asal Indonesia di pasar mancanegara. Hal ini akan menyebabkan meningkatnya permintaan akan produk ekspor Indonesia. Dampak positif dari melemahnya nilai tukar riil dirasakan oleh perusahaan ataupun pelaku bisnis yang berorientasi ekspor. Turunnya nilai tukar riil memungkinkan eksportir menerima profit margin yang semakin lebar apabila eksportir tidak mengurangi harga jual. 
Hasil penelitian ini juga menunjukkan bahwa tingkat suku bunga riil berpengaruh negatif dan signifikan terhadap IHSG. Kenaikan tingkat bunga memiliki dampak negatif terhadap setiap emiten karena akan meningkatkan beban bunga kredit dan menurunkan laba bersih. Penurunan laba bersih akan mengakibatkan laba per saham juga menurun dan akhirnya akan berakibat turunnya harga saham di pasar. Di sisi lain, naiknya suku bunga akan mendorong investor untuk menjual saham dan kemudian menabung hasil penjualan itu dalam deposito.

\section{SIMPULAN DAN SARAN}

Berdasarkan hasil penelitian dan pembahasan yang telah dikemukakan, maka dapat disimpulkan beberapa hal sebagai berikut: Nilai Tukar Riil mempunyai pengaruh positif dan signifikan terhadap IHSG. Hal ini bermakna bahwa nilai tukar riil secara substansial akan mempengaruhi nilai dari suatu perusahaan dan pada akhirnya akan berpengaruh kuat pada harga saham. Tingkat Suku Bunga Riil mempunyai pengaruh negatif dan signifikan terhadap IHSG. Kenaikan tingkat suku bunga dapat meningkatkan beban perusahaan (emiten) yang lebih lanjut dapat menurunkan harga saham. Kenaikan ini juga potensial mendorong investor mengalihkan dananya ke pasar uang atau tabungan maupun deposito sehingga investasi di lantai bursa turun dan selanjutnya dapat menurunkan harga saham.

Berdasarkan kesimpulan, maka dapat diberikan beberapa saran yang dapat diaplikasikan diantaranya: Investor sebaiknya meng update informasi mengenai nilai tukar riil dan tingkat suku bunga riil karena variabel tersebut berpengaruh 
terhadap IHSG di Bursa Efek Indonesia (BEI) yang dapat digunakan sebagai salah satu dasar pengambilan keputusan investasi. Untuk penelitian yang akan datang yang berkaitan dengan Indeks Harga Saham Gabungan (IHSG), diharapkan mengembangkan alat ukur yang lebih spesifik yang berasal dari dalam negeri (internal) seperti PDB, jumlah uang yang beredar, tingkat pengangguran, dan faktor yang berasal dari luar negeri (eksternal) seperti harga emas dunia, harga minyak dunia, dan indeks bursa negara lain.

\section{REFERENSI}

Abdelaziz, Mohamed, Georgios Chortareas and Andrea Cipollini. (2014). "Stock Prices, Exchange Rates, and Oil: Evidence from Middle East OilExporting Countries". Topics in Middle Eastern and African Economies. $10(2), 1-27$

Adiningsih, Sri dkk. (2014). Perangkat Analisis dan Teknik Analisis Investasi di Pasar Modal Indonesia. Jakarta: P.T. Bursa Efek Jakarta.

Adiwarman, K. (2014). Mengantisipasi Dampak Krisis Keuangan Global. Jakarta: Impresario BRI.

Alam, Md. Mahmudul and Md. Gazi Salah Uddin. (2013). "Relationship between Interest Rate and Stock Price: Empirical Evidence from Developed and Developing Countries". International Journal of Business and Management. 4 (3), 43-51

Albuquerque, Christiane R. and Marcelo S. Portugal. (2012). "Exchange Rate and Inflation: A Case of Sulkiness of Volatility". International Journal of Business and Management. 2 (2), 1-30

Alexandra, Horobet and Ilie Livia. (2014). "Real Exchange Rates and Stock Prices: Insights Into the Competitiveness of Romanian Economy". Studies in Business and Economics. 1 (2), 30-40

Ali, Tariq Mahmood, Muhammad Tariq Mahmood and Tariq Bashir. (2015). "Impact of Interest Rate, Inflation and Money Supply on Exchange Rate Volatility in Pakistan”. World Applied Sciences Journal. 33 (4), 620-630 
Ananto, Bagus. (2014). “Analisis Pengaruh Inflasi, Nilai Tukar, Dan Suku Bunga Terhadap Indeks Harga Saham Gabungan Jakarta Islamic Index (JII)". Jurnal Ekonomi. 2 (1), 1-25

Anoraga, Pandji dan Piji Pakarti. (2011). Pengantar Pasar Modal. Jakarta: PT Rineka Cipta.

Arikunto, S. (2012). Prosedur Penelitian Suatu Pendekatan Praktik. Jakarta: Rineka Cipta.

Bapepam. (2015). Studi tentang Penerapan ESOP Perusahaan Publik di Pasar Modal Indonesia. Departemen Keuangan Republik Indonesia.

Bergin, Paul R. and Steven M Sheffrin. (2012). "Interest Rates, Exchange Rates and Present Value Models of The Current Account". The Economic Journal. 1 (1), 535-558

Bursa Efek Indonesia (BEI). (2012). Buku Panduan Indeks Harga Saham Bursa Efek Indonesia. Bursa Efek Indonesia.

Efni, Yulia. (2012). "Pengaruh Suku Bunga Deposito, SBI, Kurs dan Inflasi Terhadap Harga Saham Perusahaan Real Estate dan Property di BEI". Jurnal Ekonomi. 2 (2), 1-12

Engel, Charles. (2016). "Exchange Rates, Interest Rates, and the Risk Premium". American Economic Review. 106 (2), 436-474

Ghozali, Imam. (2012). Aplikasi Analisis Multivariate Dengan Program SPSS. Semarang: Badan Penerbit Undip.

Halim, Abdul. (2013). Analisis Investasi. Edisi Kedua. Jakarta: Salemba Empat.

Hardiningsih. (2012). "Pengaruh Faktor Fundamental dan Resiko Ekonomi terhadap Retrun Saham Pada Perusahaan di BEJ, Studi Kasus Basic Industry \& Chemical”, Jurnal strategi bisnis, Universitas Diponegoro.

Hismendi, Abubakar Hamzah, dan Said Musnadi. (2013). Analisis Pengaruh Nilai Tukar Rupiah, SBI, Inflasi, dan Pertumbuhan GDP Terhadap Pergerakan Indeks Harga Saham Gabungan di Bursa Efek Indonesia. Jurnal Ilmu Ekonomi. 1 (2), 112-128 
Husnan, Suad. (2015). Dasar-dasar Teori Portofolio dan Analisis Sekuritas di Pasar Modal. Yogyakarta: UPP AMP YKPN.

Jawaid, Syed Tehseen and Anwar Ul Haq. (2012). "Effects of Interest Rate, Exchange Rate and Their Volatilities on Stock Prices: Evidence From Banking Industry of Pakistan”. Theoretical and Applied Economics. 19 (8), 153-166

Jayanti, Yusnita, Darminto dan Nengah Sudjana. (2014). "Pengaruh Tingkat Inflasi, Tingkat Suku Bunga SBI, Nilai Tukar Rupiah, Indeks Dow Jones, dan Indeks Klse terhadap Indeks Harga Saham Gabungan (IHSG)". Jurnal Administrasi Bisnis (JAB). 11 (1), 1-10

Jogiyanto, H., (2010). Teori Portofolio dan Analisis Investasi. Yogyakarta: BPFE.

Kadir, Hazlina Binti Abd., Zarehan Selamat, Therisanyo Masuga and Reetsang Taudi. (2011). "Predictability Power of Interest Rate and Exchange Rate Volatility on Stock Market Return and Volatility: Evidence from Bursa Malaysia". International Conference on Economics and Finance Researc. $4(1), 105-110$

Kewal, Suramaya Suci. (2012). "Pengaruh Inflasi, Suku Bunga, Kurs, dan Pertumbuhan Pdb terhadap Indeks Harga Saham Gabungan”. Jurnal Economia. 8 (1), 53-64

Khan, Zohaib, Sangeen Khan, Lala Rukh, dan Imdadullah. (2012). Impact of Interest Rate, Exchange Rate, and Inflation on Stock Return of KSE 100 Index. IJER. 3 (5), 142-155

Kuncoro, Mudrajad. (2011). Manajemen Keuangan Internasional. Yogyakarta: BPFE.

Madura, Jeff. (2013). International Corporate Finance. Keuangan Perusahaan Internasional. Jakarta: Salemba Empat.

Mankiw, N. G., (2012). Teori Makro Ekonomi. Edisi kelima. Alih Bahasa Imam Nurmawan. Jakarta: Erlangga.

Manurung, Jonni dan Adler Haymans Manurung. (2013). Ekonomi Keuangan dan Kebijakan Moneter. Jakarta: Salemba Empat. 
Marzuki. (2010). Metodologi Riset. Yogyakarta: BPFE-UII.

Menike. (2013). "The Effect of Macroeconomic Variables On Stock Prices In Emerging Sri Lankan Stock Market". Sabaragamuwa University Journal, Vol. 6. No 1. 6 (1), 55-75

Mgammal, Mahfoudh Hussein Hussein. (2012). "The Effect of Inflation, Interest Rates and Exchange Rates on Stock Prices Comparative Study Among Two Gcc Countries". International Journal of Finance and Accounting. 1 (6), 179-189

Muhammad, Naeem and Abdul Rasheed. (2014). "Stock Prices and Exchange Rates: Are they Related? Evidence from South Asian Countries". Journal of Business and Management. 1 (1), 231-254

Mulyadi. (2011). Sistem Akuntansi. Jakarta: Salemba Empat.

Mulyani, Neny. (2014). "Analisis Pengaruh Inflasi, Suku Bunga, Nilai Tukar Rupiah, Dan Produk Domestik Bruto Terhadap Jakarta Islamic Index”. Jurnal Bisnis dan Manajemen Eksekutif. 1 (1), 36-71

Murtianingsih. (2012). "Variabel Ekonomi Makro dan Indeks Harga Saham Gabungan”. Jurnal Manajemen dan Akuntansi. 1 (3), 1-12

Nofiatin, Ike. (2013). "Hubungan Inflasi, Suku Bunga, Produk Domestik Bruto, Nilai Tukar, Jumlah Uang Beredar, dan Indeks Harga Saham Gabungan (IHSG) Periode 2005-2011”. Jurnal Apnlamikaa Osir Amnagnajemen. Vol. 11. No. 2. 11 (2), 120-135

Nordin, Norhafiza, Sabariah Nordin dan Rusmawati Ismail. (2014). "The Impact of Commodity Prices, Interest Rate and Exchange Rate on Stock Market Performance: An Empirical Analysis From Malaysia”. Malaysian Management Journal. 18 (1), 39-52

Novianto, Aditya. (2011). "Analisis Pengaruh Nilai Tukar (KURs) Dolar Amerika/Rupiah (US\$/Rp), Tingkat Suku Bunga Sbi, Inflasi, dan Jumlah Uang Beredar (M2) terhadap Indeks Harga Saham Gabungan (Ihsg) di Bursa Efek Indonesia (BEI) Periode 1999.1 - 2010.6”. Jurnal EKonomi dan Manajemen. 1 (1), 1-8 
Nugraha, I Wayan Wahyu dan I Made Rusmala Dewi. (2015). “Pengaruh Tingkat Suku Bunga SBI, Nilai Tukar dan Indeks Pasar Dunia pada IHSG di BEI". Jurnal Manajemen, Strategi Bisnis dan Kewirausahaan. 9 (1), 34-41

Octafia, Sri Mona. (2012). "Pengaruh Tingkat Suku Bunga SBI, Nilai Tukar dan Jumlah Uang Beredar terhadap Indeks Harga Saham Sektor Property dan Real Estate dengan Pendekatan Error Correction Model". Jurnal EKonomi dan Manajemen. 1 (1), 1-12

Palatte, Muh. Halim dan Akbar. (2014). "Pengaruh Nilai Tukar Mata Uang dan Tingkat Suku Bunga terhadap Perkembangan Indeks Harga Saham Gabungan di Bursa Efek Indonesia Periode 2009-2013". Jurnal Manajemen. 1 (2), 39-57

Pohan, Aulia. (2014). Potret Kebijakan Moneter Indonesia. Jakarta: PT. Raja Grafika Persada.

Prawoto, Hudi dan Amos Amoroso Avonti. (2014). “Analisis Pengaruh Nilai Tukar Rupiah/US\$ dan Tingkat Suku Bunga SBI Terhadap Indeks Harga Saham Gabungan di Bursa Efek Jakarta”. Jurnal Akuntansi Bisnis. 3 (5), $65-80$

Purnomo, Tri Hendra dan Nurul Widyawati. (2013). "Pengaruh Nilai Tukar, Suku Bunga, dan Inflasi terhadap Return Saham pada Perusahaan Properti”. Jurnal Ilmu dan Riset Manajemen. Vol. 2. No. 10. 2 (10), 130-150

Rizal, Jose. (2014). Pasar Uang dan Pasar Valuta Asing. Jakarta : Salemba Empat

Salvatore. (2014). Ekonomi Internasional. Jilid 2. Alih Bahasa Haris Munandar. Jakarta: Erlangga.

Semuel, Hatane and Stephanie Nurina. (2015). "Analysis of the Effect of Inflation, Interest Rates, and Exchange Rates on Gross Domestic Product (GDP) in Indonesia". Proceedings of the International Conference on Global Business, Economics, Finance and Social Sciences. 23 (2), 950978

Sholihah, Mar'atus. (2014). “Analisis Pengaruh Suku Bunga, Inflasi, dan Nilai Tukar Terhadap Harga Saham pada Perusahaan Jasa Perhotelan dan 
Pariwisata Yang Terdaftar di Bursa Efek Indonesia”. Naskah Publikasi Universitas Muhammadiyah Surakarta. 1 (2), 20-45

Sugiyono. (2014). Metode Penelitian Kuantitatif, Kualitatif, dan Kombinasi (Mixed Methods). Bandung: Alfabeta.

Sukirno, Sadono. (2012). Makro Ekonomi. Edisi Ketiga. Jakarta: PT. Raja Grafindo Persada.

Sukono, Bambang dan Indarto. (2012). “Analisis Faktor-faktor yang Mempengaruhi IHSG di Bursa Efek Indonesia Periode Tahun 2007-2011”. Jurnal Dinamika Manajemen. 1 (2), 1-28

Sunariyah. (2012). Pengantar Pengetahuan Pasar Modal. Jakarta: Erlangga.

Supriyono. (2014). Akutansi Biaya Pengumpulan Biaya dan Penentuan Harga Pokok Produksi. Yogyakarta: BPFE Universitas Gajah Mada.

Tandelilin, E., (2014). Analisis Investasi dan Manajemen Fortofolio. Yogyakarta: BPFE.

Tobing, Wilson L., Adler Haymans Manurung dan Pananda Pasaribu. (2013). "Pengaruh Variabel Makro Ekonomi Terhadap IHSG". Jurnal Universitas Indonesia. 3 (2), 55-70

Turkyilmaz, Serpil and Mesut Balibey. (2013). "The relationships among interest rate, exchange rate and stock price: A Bekk - Mgarch Approach". International Journal of Economics, Finance and Management Sciences. 1 (3), 166-174

Utami, Mudji dan Mudjilah Rahayu. (2013). "Peranan Profitabilitas, Suku Bunga, Inflasi dan Nilai Tukar dalam Mempengaruhi Pasar Modal Indonesia Selama Krisis Ekonomi”. Jurnal Manajemen dan Kewirausahaan. 5 (2), $123-131$

Wardani, D. K. (2013). "Pengaruh Struktur Kepemilikan Terhadap Nilai Perusahaan Dengan Kinerja Keuangan dan Kebijakan Hutang sebagai Variabel Intervening”. Jurnal Siasat Bisnis. 15 (1), 27-36. 